ISSN 1112-9867

http://www.jfas.info

\title{
SMALL AND MEDIUM ENTERPRISES (SMES) FUTURE DEVELOPMENT: A COMPREHENSIVE REVIEW ON CUSTOMER RETENTION PROGRAMME IN RETAINING CUSTOMER LOYALTY
}

\author{
H. A. Mohd Abd Majid ${ }^{1 *}$, S. N. F. Ahmad Sharif ${ }^{1}$, S. N. Sulong ${ }^{1}$, M. Omar ${ }^{2}$, and S. N. Syed \\ Yassin $^{3}$, R. Raju ${ }^{3}$, Z. Zakaria ${ }^{3}$, and F. Mahamed Ali ${ }^{1}$ \\ ${ }^{1}$ Faculty of Hotel and Tourism Management, Universiti Teknologi MARA, Dungun, \\ Terengganu, Malaysia \\ ${ }^{2}$ Taylors Universiti, Lake Side Campus, Selangor Malaysia \\ ${ }^{3}$ Faculty of Computer and Mathematical Science, Universiti Teknologi MARA, Terengganu, \\ Malaysia
}

Published online: 17 October 2017

\begin{abstract}
Customer retention programme is a marketing strategy that aims to increase customer loyalty by giving benefits. This study aims to analyse the advantages and disadvantages of the types of customer retention that may help to foster business among small and medium enterprises (SMEs) future development. This study reveals that advantage card is the most preferred programme, being the most common retention programme used by retail store operators worldwide and the most suitable to be implemented in the retail store operation. It can concluded that, customer retention programme is crucial to customer loyalty, and the retailer should take this opportunity to improve customer loyalty and repurchase behaviour.
\end{abstract}

Keywords: small and medium enterprises (SMEs); customer retention program; loyalty; advantage card; monetary reward.

Author Correspondence, e-mail: hayati2959@tganu.uitm.edu.my doi: http://dx.doi.org/10.4314/jfas.v9i5s.70 


\section{INTRODUCTION}

Small and medium enterprises (SMEs) are essential to the improvement of economies everywhere throughout the world, especially in providing and servicing nations by offering jobs, utilizing nearby assets, reducing poverty and improving the quality of life [1].This can subsequently expand the accomplishment of SMEs and allow its potential to be explored and leveraged.

It is undoubted that the achievement of any business is dictated by faithful clients that build up a preference for that business [2]. Nowadays, technology is helping the marketing executives in creating different plans of consumer retaining programme. Recently, the popularity of customer retention programme has attracted widespread attention to marketing scholars. Most of the research is focusing on investigating how this programme can contribute to the company's financial and marketing performance [2]. In establishing retail markets, many companies adopted customer-focused strategy via a formal programme, namely the Customer Relationship Programme (CRP). With the advancement of information and communication technology (ICT), marketing executives are required to utilise the resources to generate new customer retaining programme plan.

Retail business in Malaysia is confronting an incredible revolution from the early days with the invention of various kinds of trading structures that promote varieties of products. Meanwhile, the retail industry is still dominated by the small local and convenience stores. Nevertheless, the growth of the economy in a long term has strengthened the progression of the domestic and international retailers which came in a form of western-styled convenience stores such as 7-eleven and D-Lima. The retailer also brought together the western-styled warehouse clubs (i.e. Reject Shop and Factory Outlets), hypermarket (i.e. Giant, Carrefour, and Tesco), and department stores (i.e. Isetan, Jusco, and Metrojaya) [3].

In a retail system, the promotion concept is an organizational framework that focuses on a company to decide the need for its market's goals and apply this needeffectively and efficientlyas compared to its competitors. Therefore, this study attempts to explore forms of customer retention programme that can be offered by retail stores towards customer loyalty $[3]$. 


\subsection{Customer Retention Programs}

Customer loyalty means client attitude and character to prefer one brand over the other. It encourages the customer to purchase regularly. It can be seen that the consumer loyalty is the nature of customer to buy the store's products or accommodations over another cheap ones in the same range [14].Besides, an effective plan of brand loyalty results in consumer retention, hence lead to profits to the company [8]. There are numerous terms to describe loyalty programmes such as reward, frequency reward, frequent-shopper, frequent flyer, loyalty or schemes card, point's cards, advantage cards, club card, and reward card [15]. These programmesusually identify the card owner as a follower in a retention programme [14]. Hence, according to the survey and previous study review, it was reported that the three most practiced customer retention programme are the monetary reward, reward, and advantage card. These three loyalty programmes are the most famous programmes among consumer. Thus, this study will explore more in relation to their well-known popularity.

\subsubsection{Advantage Card}

In the United Kingdom (UK), the advantage card,or also known as privilege card or loyalty cardis one of the leading customer retention programmes that has been used by over 16 million people in the UK as the card holder recognize the card's benefits [16]. This kind of card has been utilized for a long period of time and the customers who apply for it acknowledge its benefit. In India, 70\% of respondents choose to own privilege card since the accumulative points can be exchanged with other forms of benefit [27]. The loyalty card can serve a multipurpose function where it can be used as credit or debit cards, loyalty card and also Touch ' $n$ ' Go card. Hence, in achieving the objectives, the company which adopts this sort of customer retention programme prepares several forms of rewards or prizes to ensure that the customer can increase the business sale and encourage more purchasing actions.

\subsubsection{Monetary Reward}

Monetary reward is one of the customer's retention programmes that has been offered by some organizations to satisfy their customer. In this programme, the prize or reward comes in many forms for instance voucher, bonus point, and cash. The consumer can redeem all these 
benefits right after the purchasing transaction. It is usually applied in credit card companies that offer rewards in exchange for the points collected when using the credit card. Sometimes, the consumer can redeem the points with the money. Other than that, this type of rewards can also be fundamental in order to change from a neutral consumer to a devoted consumer. Therefore, this type of programme can be the first move in order to attract the consumer and turn them into a loyal customer to the company.

\subsubsection{Reward/Non-monetary reward}

There are two types of rewards after purchasing which are postponed rewards or instant rewards. In the privilege rewards, the consumer gains the advantage directly after purchasing such as the complementary voucher or coupon. However, in the postponed rewards, the consumer must return to the company to get the rewards [22]. The rewards additionally are the special gift given to the customer once they purchase aproduct or services such as accommodation. The rewards come in many types for instance points, vouchers, presents and many more. Day by day, the rewards are increasing and become more appealing between the companies. It was reported that approximately $50 \%$ of US populace is involved in the consumer retention programme [28]. Besides, $76 \%$ of the US grocery stores and $40 \%$ of the Visa and MasterCard users are involved in the consumer reward programme.

\subsection{Problem Statement}

Nowadays, getting the customers is crucial to the success of a business. Based on the market industry, there is a pattern where many enterprises have changed from conventional advertising technique to a new advertising method. In this procedure, several components result in notable impacts that affect the client's faithfulness. In line with the fast growth of competitiveness in the trade market, the suppliers provide few customer retention programmes to increase the profit by the client repurchase action in a long-term [4]. Therefore, in an exceptionally aggressive environment, loyalty programmes have turned into an inevitably essential customer relationship programme devised to secure strong relations with their clients [5]. 
Previous study on the efficiency of the loyalty programme has been described and it stated that the programme certainly does not increase the allegiance and is not profitable [7]. However, another study reported that the loyalty or retention programme increases the clients' faithfulness and is profitable as supported by previous studies that showed retention programmes have a good outcome on clients' visit choice and their purchasing activity [11] [12]. Retaining programme also focuses on the commitment of the company as well as the consumer in order to maintain the programme [11]. In addition, understanding the programme itself can decrease the cost-inefficiency of retaining programme. Hence, before implementing the programme to the consumer, the organization should access the programme so that a better connection between company and customer can be achieved [13].

The loyalty programme is a well-known phenomenon in Malaysia which is a "must-do" strategy for small or big retailers. They choose to initiate their identifiable loyalty programmes that stated their company on the advantage card (i.e. J-Card, Privileges Card, I-Club Card, MJ). Some people are becoming significance followers of multi-membership retention programmes (Real Rewards, Bonus Link, Enrich). These programmes are beneficial to the retail stores in Malaysia to result in an extraordinary impact on store's trades. Despite the abundance of customer loyalty programme research and emerging perspectives, those companies must change from the ordinary circumstance by preparing an offer of equal advantage to the participating clients. Nevertheless, the main point is which customer retention programme inspires the consumer and to what extent it can be persistent? Thus, this study will discuss in depth the common type of loyalty programmes including their advantages and disadvantages in retaining customer loyalty that may help to foster businesses and SME's future development.

\section{METHODOLOGY}

\subsection{The Search Strategy}

This review targeted the reliable precedent journal articles, newspapers, and electronic databases under the keyword of "small and medium enterprises", "customer retention", "customer loyalty", "advantage card", and "monetary reward". The databases were mainly accessed from different online resources such as Emerald, Science Direct, Scopus, 
Demeanorand others. All the linked data were gathered and discussed accordingly to create a complete comprehension about Customer Retention Programme.

In this paper, a total of 30 articles have been observed. An overview of the customer retention programmes was done and continued by focusing on the most commonly used programs (i.e: advantage card, monetary reward and reward). Five authors have been chosen to review their opinions in terms of the advantages and disadvantages for each programme. Their opinions were extracted and discussed further for the advantages and disadvantages as specified in the table, to be compared. This deepens the look for each customer retention programme that may help the sales of retail stores. The journals were selected, including Journal of Marketing Retail, Research Journal of Economics and Business Studies, Journal of Targeting, Measurement, and Analysis for Marketing, International Research in Marketing, Journal of Academy of Business and Economics, European Journal of Marketing, International Journal of Service Industry Management, and Journal of Retailing and Consumer Services. The search selected all English titles and covers the part related to customer retention programmes.

\subsection{Review Strategy}

This review is intended to analyse the advantages and disadvantages of the advantage card program, reward program and monetary reward program. For this reason, the reviewers have read and extracted the points that answered the question and list them in a structured table. Then, the points are analysed and summarized. Lastly, the results and the gaps found are discussed.

\section{COMPREHENSIVE REVIEW ON CUSTOMER RETENTION PROGRAMME}

Among the research articles observed, many customer retention programmes have been identified. However, only articles related to advantage card, monetary reward and rewardshave been extensively studied. As aforementioned, five authors for each programme have been chosen to review their opinion in order to extract and compare the advantages and disadvantages of each programme. The findings are believed to be vital information for the retail stores in improving their marketing strategies. The findings are illustrated in Table 1, 2 
and 3 respectively for advantage card, monetary reward and rewads/non-monetary reward.

Table 1. Advantages and disadvantages of advantage card programme

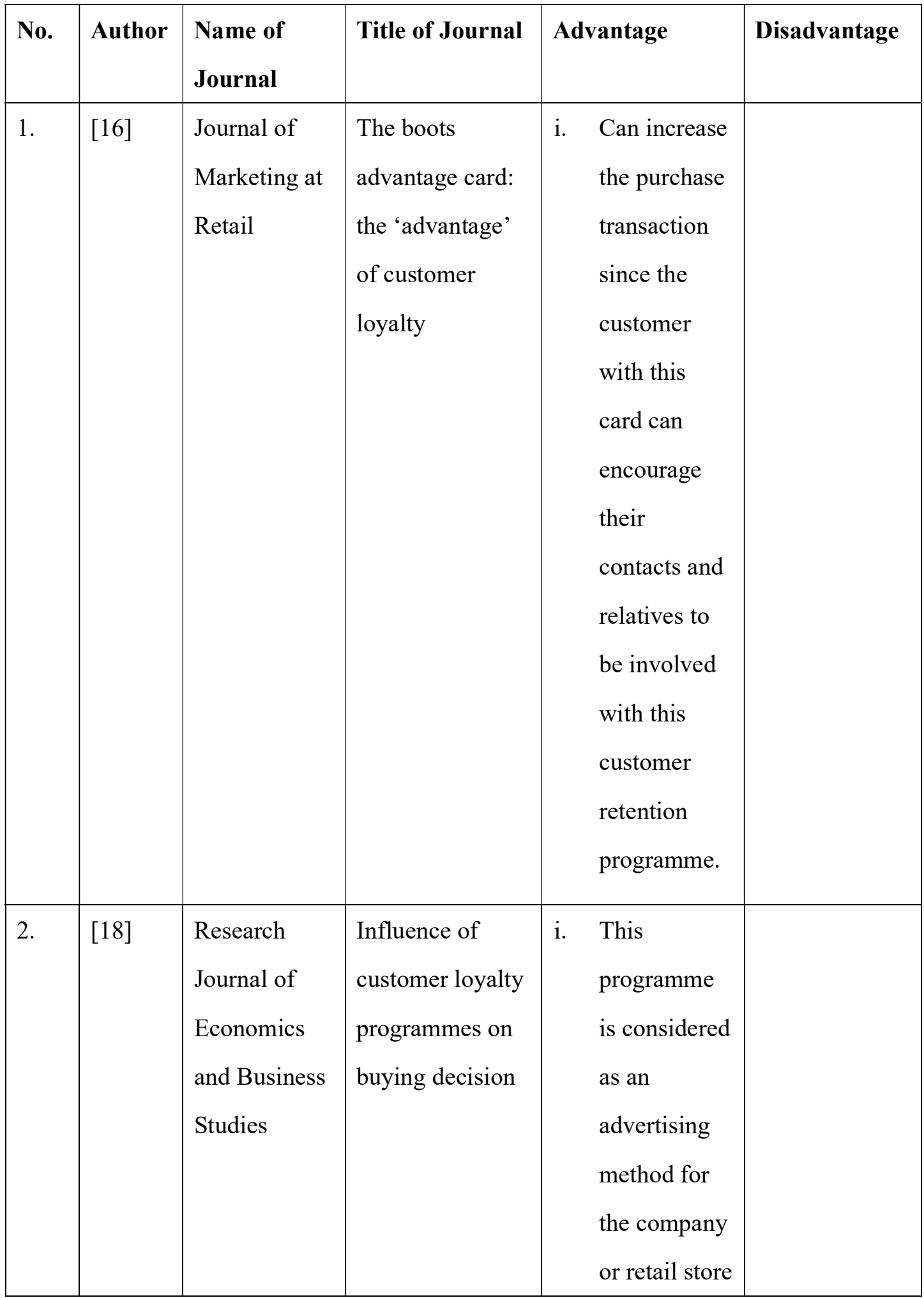




\begin{tabular}{|c|c|c|c|c|c|}
\hline & & & & $\begin{array}{l}\text { that focuses } \\
\text { on } \\
\text { preserving } \\
\text { current } \\
\text { clients } \\
\text { instead of } \\
\text { getting new } \\
\text { clients. }\end{array}$ & \\
\hline 3. & [11] & $\begin{array}{l}\text { Journal of } \\
\text { Marketing }\end{array}$ & $\begin{array}{l}\text { The long-term } \\
\text { impact of loyalty } \\
\text { programmes on } \\
\text { consumer } \\
\text { purchase } \\
\text { behavior and } \\
\text { loyalty }\end{array}$ & $\begin{array}{l}\text { i. In addition } \\
\text { to gaining } \\
\text { advantage } \\
\text { from the } \\
\text { existing } \\
\text { consumers, } \\
\text { the company } \\
\text { can decrease } \\
\text { the budget of } \\
\text { probing new } \\
\text { consumers. }\end{array}$ & \\
\hline
\end{tabular}




\begin{tabular}{|c|c|c|c|c|c|c|}
\hline 4. & [19] & $\begin{array}{l}\text { International } \\
\text { Journal of } \\
\text { Economic } \\
\text { Practices and } \\
\text { Theories }\end{array}$ & $\begin{array}{l}\text { The loyalty card: } \\
\text { issues in } \\
\text { evaluating } \\
\text { loyalty } \\
\text { programme } \\
\text { effectiveness }\end{array}$ & ii. & $\begin{array}{l}\text { This card } \\
\text { allows } \\
\text { customers to } \\
\text { redeem their } \\
\text { cumulative } \\
\text { points with } \\
\text { anything } \\
\text { from the list. } \\
\text { Special in } \\
\text { self-protectiv } \\
\text { e features in } \\
\text { which the } \\
\text { informationc } \\
\text { ontained in } \\
\text { this card can } \\
\text { only be } \\
\text { accessed by } \\
\text { the company } \\
\text { and the card } \\
\text { owner. } \\
\text { this card can } \\
\text { be used over } \\
\text { an extended } \\
\text { period of } \\
\text { time. In } \\
\text { ownership of }\end{array}$ & $\begin{array}{l}\text { i. Needs a } \\
\text { huge } \\
\text { budget to } \\
\text { be } \\
\text { implemente } \\
\text { d and it can } \\
\text { exceed the } \\
\text { income of } \\
\text { the } \\
\text { company. }\end{array}$ \\
\hline
\end{tabular}




\begin{tabular}{|c|c|c|c|c|c|c|}
\hline & & & & & $\begin{array}{l}\text { this card can } \\
\text { transferred to } \\
\text { another } \\
\text { individual } \\
\text { when the } \\
\text { owner } \\
\text { deceased. }\end{array}$ & \\
\hline 5. & [9] & $\begin{array}{l}\text { International } \\
\text { Journal of } \\
\text { Service } \\
\text { Industry } \\
\text { Management }\end{array}$ & $\begin{array}{l}\text { The effect of } \\
\text { customer card } \\
\text { programs }\end{array}$ & \begin{tabular}{|l} 
i. \\
\\
ii. \\
ii.
\end{tabular} & $\begin{array}{l}\text { The card } \\
\text { programs } \\
\text { influence } \\
\text { customers' } \\
\text { behaviourand } \\
\text { loyalty. } \\
\text { Dutch results } \\
\text { reported that } \\
\text { the effect of } \\
\text { these } \\
\text { programs on } \\
\text { attitudinal } \\
\text { loyalty is } \\
\text { more } \\
\text { long-lasting } \\
\text { that on } \\
\text { behavioural } \\
\text { loyalty. }\end{array}$ & $\begin{array}{l}\text { ii. The } \\
\text { effectiven } \\
\text { ess of the } \\
\text { card } \\
\text { programs } \\
\text { seems to } \\
\text { reduce } \\
\text { with the } \\
\text { increase } \\
\text { of } \\
\text { alternative } \\
\text { card } \\
\text { programs } \\
\text { in the } \\
\text { market, as } \\
\text { well as } \\
\text { with the } \\
\text { behaviour } \\
\text { of }\end{array}$ \\
\hline
\end{tabular}




\begin{tabular}{|l|l|l|l|l|}
\hline & & & & consumers \\
& & & & with the \\
& & & & cards. \\
\hline
\end{tabular}

Generally, this research found that advantage card is the most popular retention programme that helps to retain the customer. Thiskind of programme usually collect all the clients' purchasing activities, which canincreases the individual relationship with the company and thus creating the customer retention to the company. The increase of transactions is also contributed by customers that have advantage card. In the meantime, the customer with this card can encourage their contact and relatives to be involved with this customer retention programme [16]. Hence, due to the subsistence of the card, the consumers' purchasing activity is increasing. The consumers will come back to the retailers since they receive an extraordinary service when they own the advantage card. Thus, the primary concern is served for the customers that own the advantage card.

Other than that, based on [18], this kind of program is considered as advertising method of the store since it preserves current clients instead of gaining the new one [18]. Moreover, the customers' details that were obtained when they register for the programme can be utilized to give promoting data.This is where the communication and advertising are applied simultaneously. Each data on the purchasing can be utilized by changing it into significant cost to raise the benefits. They can utilize it as a benefit by making direct promotions, sales or discounts that undoubtedly will stimulate the consumer to create more purchase activity. The increase in purchase activity results in an increase in income which can be gained by the retailer and at some point it can result in income expansion. It was also supported by [11] which reported that the company can decrease the budget of getting new consumers and obtain the advantage from the existing consumers [11].

Besides, the ordinary utilization of this beneficial card is to accumulate points while purchasing products at the retail department. The consumers can utilize or redeem the accumulated points once they have adequate collectible points. The reclamation of the collected points can allow the customer to gain advantages or prizes from the company such 
as a rebate for another purchase deal or discounts according to the quantity of collectible points. In a study carried out by [19], the researcher also found that this advantage card allows customers to utilize their cumulative points for inessential thing. For example, the consumer can exchange the cumulative points with a holiday voucher that required specific points.

In addition, the advantage card owner can also obtain the special treatment during sale seasons. Card owners will be notified on the sale via newletters, emails or telephone as the company has obtained their personal details during registration. Therefore, this allowsthe customers with the card to firstly arrive at the store as compared to other neutral customer without the card. Hence, based on the customers' view, they will sense that they are being valued since they were notified of the sale earlier than other individuals. Tesco has practiced this idea whereby the consumer with this advantage card will be informed first of the sale than other individuals.

However, this type of loyalty programme has a few disadvantages. Back in 2004, [9] in their study found that the effectiveness of this card is reduced with the increase in number of similar card programmes offered by other companies [9]. Other than that, it was also reported by [19] that this kind of program requires a large amount of budget and sometimes can exceed the company's income [19]. Thus, to ensure the success of this programme, the store should educate the consumer on the instructions and guidelines to be followed by the consumer so that they can gain benefits of the card [19]. Hence, the store should give all the details to the consumer so that they can obtain benefits from the card. Since the budget to obtain new client is more costly than to retain it, a good leader must concentrate to retain the current client and practice worthy guideline so that the client's faithfulness can be ensured [20].

Moreover, advantage card is different from other kinds of customer retention programme especially in terms of self-protective features in which the informationcontained in this card is only accessible by the company and the card owner. Besides, this card also provides benefits in extended period of time as the rights of this card can be handed to another individual when the owner deceased, as practice in some companies [19]. Hence, it can be seen that the connection between consumer and company can remain strong even for an extended period when utilising this advantage card. 
Table 2. Advantages and disadvantages for monetary reward programme

\begin{tabular}{|c|c|c|c|c|c|}
\hline No & Author & Name of Journal & Title of Article & Advantage & Disadvantage \\
\hline 1. & {$[13]$} & $\begin{array}{l}\text { Journal of } \\
\text { Targeting, } \\
\text { Measurement }\end{array}$ & $\begin{array}{l}\text { Designing competitive } \\
\text { loyalty programmes: } \\
\text { How } \\
\text { types of programmeaffe } \\
\text { customer equity. }\end{array}$ & $\begin{array}{l}\text { i. Consumers } \\
\text { are capable } \\
\text { of } \\
\text { performing } \\
\text { 'exchange' } \\
\text { of the } \\
\text { reward } \\
\text { values into } \\
\text { money. } \\
\text { ii. This } \\
\text { programme } \\
\text { will result in } \\
\text { an increase } \\
\text { in the } \\
\text { number of } \\
\text { consumer } \\
\text { joining the } \\
\text { loyalty } \\
\text { programmes } \\
\text { since it } \\
\text { allows the } \\
\text { consumer to } \\
\text { obtain the } \\
\text { reward after } \\
\text { joining the } \\
\text { program for } \\
\text { only } 6 \\
\text { months. } \\
\text { iii. Monetary } \\
\text { reward } \\
\text { creates a } \\
\text { good service } \\
\text { views from } \\
\text { the } \\
\text { consumers } \\
\text { that can } \\
\text { change them } \\
\text { from a } \\
\text { neutral } \\
\text { consumer to } \\
\text { covoted } \\
\text { aner. }\end{array}$ & \\
\hline
\end{tabular}




\begin{tabular}{|c|c|c|c|c|c|}
\hline 2. & {$[24]$} & $\begin{array}{l}\text { European } \\
\text { Journal of } \\
\text { Marketing }\end{array}$ & $\begin{array}{l}\text { The influence of } \\
\text { loyalty programme } \\
\text { membership on } \\
\text { customer } \\
\text { purchase behaviour }\end{array}$ & $\begin{array}{l}\text { i. Give } \\
\text { positive } \\
\text { effect on } \\
\text { different } \\
\text { aspects of } \\
\text { behavioural } \\
\text { loyalty. }\end{array}$ & \\
\hline 3. & [31] & $\begin{array}{l}\text { Journal of } \\
\text { Marketing } \\
\text { Research }\end{array}$ & $\begin{array}{l}\text { Decomposing the } \\
\text { promotional revenue } \\
\text { bump for } \\
\text { loyalty program } \\
\text { members versus } \\
\text { non-members }\end{array}$ & $\begin{array}{l}\text { i. Discounts } \\
\text { obtained by } \\
\text { the } \\
\text { consumer } \\
\text { can } \\
\text { enhance the } \\
\text { consumers' } \\
\text { purchase } \\
\text { activity }\end{array}$ & \\
\hline 4. & [21] & $\begin{array}{l}\text { International } \\
\text { Research in } \\
\text { Marketing }\end{array}$ & $\begin{array}{l}\text { When Giving Money } \\
\text { Does Not Work: The } \\
\text { Differential Effects Of } \\
\text { Monetary Versus } \\
\text { In-Kind Rewards In } \\
\text { Referral Reward } \\
\text { Programmes. }\end{array}$ & & $\begin{array}{l}\text { i. When the } \\
\text { brand is } \\
\text { powerless, } \\
\text { the } \\
\text { monetary } \\
\text { rewards } \\
\text { are } \\
\text { reflected } \\
\text { to be } \\
\text { ineffective } \\
\text {. }\end{array}$ \\
\hline 5. & [22] & $\begin{array}{l}\text { Journal of } \\
\text { Academy of } \\
\text { Business and } \\
\text { Economics }\end{array}$ & $\begin{array}{l}\text { Relationship Between } \\
\text { Sale Promotions, } \\
\text { Duration of Receiving } \\
\text { Reward and Customer } \\
\text { Preference: a Case } \\
\text { Study On Financial } \\
\text { Products. }\end{array}$ & & $\begin{array}{l}\text { i. } \text { This } \\
\text { reward } \\
\text { system } \\
\text { possesses } \\
\text { its } \\
\text { benefits } \\
\text { and } \\
\text { weakness } \\
\text { es and its } \\
\text { success } \\
\text { relies on } \\
\text { the } \\
\text { consumer }\end{array}$ \\
\hline
\end{tabular}




\begin{tabular}{|l|l|l|l|l|}
\hline \hline & & & & $\begin{array}{l}\text { and how it } \\
\text { is } \\
\text { designed. }\end{array}$ \\
\hline
\end{tabular}

Nevertheless, nowadays, the advantage card has anothercompetitor, for example, the monetary rewards (Table 2). In most cases of the advantage cards, the customers are required to accumulate the points until they get adequate points before they can use the points. In contrast, the monetary rewards straightway give benefits to the consumer after purchasing action. Monetary rewards comes in many types like a voucher, repast coupon or money. According to [13], even though they are of different types, the consumers are capable of performing 'exchange' of the reward values into money [13]. This kind of consumers can count their profit and forfeiture well. Moreover, the customer will sense that they are being valued by the company once they obtain their cash back after buying something. It additionally will encourage the customer to return and repurchase at the same store. It is similar to the voucher booklet, which is provided by the store to its faithful consumer to reduce their expenses. Even though the voucher's amount may be small,it can aid the consumer in preserving their cash. It definitely can touch the customer's feeling and in the meantime capable of improving customers' trust.

Besides, [24] has reported that monetary reward programme gives positive effect on different aspects of behavioural loyalty of the consumer [24]. It was supported by [13] that found that monetary reward creates a good service views from the consumers that can change them from a natural consumer to a devoted consumer [13]. The researcher also reported that consumer views on the worthiness of customer retention programs vary between the types of reward, and are dependent on the connection between the consumer and the company. Programs that appear to be beneficial by consumers will lead to their strong faithfulness and an increase in repurchasing behaviour. Therefore, this monetary reward can be utilized as the company's first step in order to influence the consumer to turn into a loyal consumer. Besides, this kind of programme should be targeted for the potential consumer,for example, the consumers who can collect adequate points within 6 months of joining the programme and thus is qualified to obtain the reward. Hence, the reward programme will result an increase in consumer joining 
the loyalty programmes [13]. Besides, according to [31] in their study reported that discounts obtained by the consumer can enhance the consumers' purchase activity [25].

However, the study carried out by [24] found that the elements in this program (i.e. saving points, discounts or cash rewards) are usually costly to the company [24]. Besides, when the brand is powerless, the monetary rewards are reflected to be ineffective. However, according to [22], this reward system possesses its benefits and weaknesses and its success relies on the consumer and how it is designed [22].

Table 3. Advantages and disadvantages for reward/non-monetary reward programme

\begin{tabular}{|c|c|c|c|c|c|}
\hline No. & Author & $\begin{array}{l}\text { Name of } \\
\text { Journal }\end{array}$ & Title of Article & Advantage & Disadvantage \\
\hline 1. & [10] & $\begin{array}{l}\text { Journal of } \\
\text { Retailing } \\
\text { and } \\
\text { Customer } \\
\text { Services }\end{array}$ & $\begin{array}{l}\text { Drivers of } \\
\text { customer } \\
\text { likehood to join } \\
\text { grocery retail } \\
\text { loyalty } \\
\text { programs. } \\
\text { An analysis of } \\
\text { reward } \\
\text { programs and } \\
\text { loyalty cards }\end{array}$ & $\begin{array}{l}\text { i. Give the } \\
\text { consumer } \\
\text { opportunity to } \\
\text { get the } \\
\text { rewards in the } \\
\text { short period. }\end{array}$ & $\begin{array}{l}\text { i. Less } \\
\text { commitment. } \\
\text { The consumers } \\
\text { only change } \\
\text { their shopping } \\
\text { behaviour for a } \\
\text { relatively short } \\
\text { period and then } \\
\text { return to their } \\
\text { usual shopping } \\
\text { pattern. } \\
\text { ii. Do not require } \\
\text { the consumer to } \\
\text { provide } \\
\text { personal data. }\end{array}$ \\
\hline 2. & [31] & $\begin{array}{l}\text { Journal of } \\
\text { Marketing } \\
\text { Research }\end{array}$ & $\begin{array}{l}\text { Decomposing } \\
\text { the promotional } \\
\text { revenue bump } \\
\text { for } \\
\text { loyalty program } \\
\text { members versus } \\
\text { non-members }\end{array}$ & $\begin{array}{l}\text { i. The member } \\
\text { of this } \\
\text { program } \\
\text { obtains extra } \\
\text { services and } \\
\text { special events } \\
\text { (e.g: extra } \\
\text { shopping } \\
\text { evenings) }\end{array}$ & $\begin{array}{l}\text { i. The company } \\
\text { provides } \\
\text { non-monetary } \\
\text { reward to } \\
\text { members only. }\end{array}$ \\
\hline 3. & [26] & $\begin{array}{l}\text { Journal of } \\
\text { Marketing }\end{array}$ & & $\begin{array}{l}\text { i. This program } \\
\text { is } \\
\text { personalized } \\
\text { based on } \\
\text { individual's }\end{array}$ & \\
\hline
\end{tabular}




\begin{tabular}{|c|c|c|c|c|c|}
\hline & & & & $\begin{array}{l}\text { requirement } \\
\text { instead of } \\
\text { being } \\
\text { identical } \\
\text { across all } \\
\text { members. } \\
\text { There will be } \\
\text { differences } \\
\text { between the } \\
\text { members (i.e. } \\
\text { elite members } \\
\text { of airlines } \\
\text { board a plane } \\
\text { first). }\end{array}$ & \\
\hline 4. & [22] & $\begin{array}{l}\text { Journal of } \\
\text { Academy of } \\
\text { Business } \\
\text { and } \\
\text { Economics }\end{array}$ & $\begin{array}{l}\text { Relationship } \\
\text { Between Sale } \\
\text { Promotions, } \\
\text { Duration of } \\
\text { Receiving } \\
\text { Reward and } \\
\text { Customer } \\
\text { Preference: a } \\
\text { Case Study On } \\
\text { Financial } \\
\text { Products. }\end{array}$ & $\begin{array}{l}\text { i. A promotion } \\
\text { that allows } \\
\text { customers } \\
\text { tobuy goods } \\
\text { or } \\
\text { accommodati } \\
\text { ons at a very } \\
\text { low price. }\end{array}$ & \\
\hline 5. & [6] & $\begin{array}{l}\text { European } \\
\text { Journal of } \\
\text { Marketing }\end{array}$ & $\begin{array}{l}\text { The effects of } \\
\text { introducing and } \\
\text { terminating } \\
\text { loyalty } \\
\text { programs }\end{array}$ & $\begin{array}{l}\text { i. The } \\
\text { non-monetar } \\
\mathrm{y} \\
\text { discriminatio } \\
\mathrm{n} \text { among the } \\
\text { members and } \\
\text { non-members } \\
\text { is more } \\
\text { operative in } \\
\text { building } \\
\text { consumer } \\
\text { faithfulness } \\
\text { compared to } \\
\text { monetary } \\
\text { components. }\end{array}$ & \\
\hline
\end{tabular}


In addition, Table 3 shows, there is another programme in retaining the customer loyalty which is reward programme. Several definitions of non-monetary reward have been proposed, and the one adopted by [22] stated it as a promotion that allows customers to buy goods at a very low price [22]. They may also gain few forms of civility or benefit that can be exchanged into money. These non-monetary rewards are prizes, points to redeem, and advantages that are obtained by the consumer once buying the stuffs or accommodations. Based on [10], the reward programme gives the consumer opportunity to get the rewards in a short period of time [10].

Besides, [26] in their study reported that this program is personalized based on individual's requirement instead of being identical with all members [26]. There will be differences between the members (i.e. elite members of airlines board a plane first). Hence, it will make the consumer feel special. As supported by [31], the member of this programme obtains extra services and special events (i.e. extra shopping evenings) [25]. Other than that, the organization of the reward programme must be planned well since it may contribute to positive outcome [30]. The design of the programme must be different from another programme in order to increase itsattractiveness. Above all, the non-monetary rewards can be measured as a successful way to attract the client. Besides, the non-monetary and monetary rewards are efficacious but it may depend on how the company practised and designed it so that it works at its best.

Nevertheless, [10] reported that non-monetary rewardprogramme requires less commitment [10]. The consumers only change their shopping behaviour for a relatively short period of time and then return to their usual shopping pattern. Moreover, they also do not require the consumer to provide personal data. Other than that, the study carried out by [6] found that the non-monetary discrimination among the members and non-members is more operative in building consumer faithfulness as compared to monetary components [6].

From these three tables, it can be clearly seen from the author's review that the advantage card has 8 advantages as compared to monetary rewards and rewards programme only have 5 advantages as compared to the latter. Besides, these three tables also showed the disadvantages of the programmes whereas advantage card programme was reported to have 2 disadvantages while monetary reward and reward programmes have 3 disadvantages 
respectively. Moreover, it can be stated that the company has utilized abundant retaining programme to preserve and attract their customers. Those programmes have their benefits and weaknesses that only can be known once we are involved and discover the packages. As a conclusion on the previous discussion, the best practice of customer retaining programme is the advantage card since the card is a prominent programme and almost all customers recognize its subsistence and purpose. This card is capable of stimulating the customers to repurchase at the similar shop since they will try to exploit the points and gain their prizes. Concurrently, it can additionally raise the customer loyalty level. Besides, this card-based programme is a programme that requires the consumer to be involved and become a member of the programme and require the consumer to relegate every time they purchase [17].

Other than that, this advantage card programme can be seen in the retail company like Isetan, Metrojaya, The Store, and Sogo that are practising a similar method. It can also be seen on the Tesco advantage card that when the card owner thinks of repurchase at the different shop, they must reconsider it since they will not have the same advantage when they shop at Tesco. Other than that, instead of using brochure or advertising board as a marketing strategy, many superstores in Malaysia like Mydin and Carrefour have also applied the advantage card programme as their promoting effort. Due to the many rewards provided by the company for the card owner, the people are encouraged to become faithful to a product or brand, and it will definitely increase the application of the privilege card. On the other hand, other researchers reported that retention programmes do not necessarily increase the consumer loyalty. It is sometimes costly and the significance is questionable. [11]. This statement may be due to results of conducted research with various objectives about retention programme that reported different results.

Moreover, [23] found that consumer's characters under the advantage card programme are different to the consumer who does not own the card. It was found that the consumer with the privilege card has a tendency to return to the store to make other purchase transactions as compared to other consumer that do not own the card. Hence, it showed that advantage card will stimulate and lead the customer to become loyal towards the retail store. It was reported that the consumer faithfulness could be affected by the customer retaining programme but [29] argued that two factors can affect the customer loyalty. One of the factors includes a lack 
of communication between the operative employees and the customers. Thisis due to the incomprehensive training of theemployees on the customer retaining programme in terms of how the accumulated points can be utilized or redeemed. The other factor that can affect customer loyalty istherewards expectation. Some of the card ownerswould expecting a discount whenbuying at the store while some would expect a more luxurious one such as holidays, free fuel coupon or indemnification. Therefore, the company, especially the employees must provide detailed information to the consumer to avoid any misinterpretations about the prizes or rewards.

\section{CONCLUSION}

Overall, it shows that aretention programme does give some positive impacts on customer loyalty and at the same time can profit the firm. To ascertain that the programme is on the right path, persistent efforts are needed to sustain the flow of the programme which eventually can foster business and SMEs development. It is recommended for the organization which had undertaken the retention programme for a long period of time, to revive their frameworks based on the present circumstance and the client response. To achieve the customers' satisfaction, the retention programme should frequently be updated. The inconsistency and outdated retaining programme can cause the loss of clients and may also give a bad reputation to the company. Besides, nowadays, the individuals are technology-savvy and even a small minute error may damage the reputation.

There are various impacts on customer retention programme and majority of them are good impacts. Besides, both customer and the retail store operator can acquire the advantage of the programmes.For instance, from the client point of view, they can improve the value of the purchased products. They also can get advantages like vouchers, discounts, repast coupon and other prizes by being involved in the programme. On the other hand, based on the retail store point of view, they can increase their income while decreasing their cost of enrolling new clients.

Based on this study, it is found that the most prevalence consumer retaining programmes utilized by the company are reward, monetary and advantage card. It was reported that the advantage card is the most preferred by the customers. This is supported by the previous 
results that demonstrate that privilege card has greater benefits as compared to the others. It can additionally be considered as the earliest and one of the most commonly used programmes. However, as previously stated, privilege card can only be utilized at a certain department store and it cannot to be utilized at a different retail store. The advantage card can be fully utilized by collaborating with other organization like the collaboration between PETRONAS and Mydin. This collaboration is beneficial to their consumer since they can collect points at both places.

In promoting the company, there are variousprogrammes that have been applied by the store, and one of them is customer retention programme. The primary objective of this programme is to retain and upsurge the client trustworthiness towards the store. The programme is essential to the company that perpetually involves with clients. This programme should be planned thoroughly by considering the consumer's preference (i.e., the socioeconomic, geographic area and demographic) in creating the best customer retention programme. Differences in the strategy of retention programmes result in different impacts to the clients. Hence, the retail store operators must decide wisely in creating the retention programmes to the consumer. The organization also must determine the consumer's desires and behaviours by conducting a consent consumer background check in order to have an excellent image of a consumer's trend, especially for SME. Hence it is undeniable that a proper plan for customer retention programme may help to foster great business and SME future developments outstandingly.

\section{ACKNOWLEDGEMENTS}

The authors would like to thanks to Department of Research and Publication, UniversitiTeknologi MARA, Dungun, Terengganu for their supports and assistants in ensuring this study successfully published.

\section{REFERENCES}

[1] Peprah J A, Mensah A O, and Akosah N B. Small and medium sized enterprise (SMEs) Accessibility to public procurement: SMEs entity perspectives in Ghana. European Journal of Business and Social Sciences, 2016, 4(11):25-40 
[2] McCall M, McMahon D. Cornell Hospitality Quarterly, 2016, 57(1), 111-115, doi:10.1177/1938965515614099

[3] Julian C C, AhmedZ U, CheAniza C W, Jamil B. Dynamics of loyalty programmes in Malaysian retailing: A strategic marketing perspective. Journal of Transnational Management, 2016, 21(3):101-114

[4] Magatef S G, Elham F T. The impact of customer loyalty programmes on customer retention. International Journal of Business and Social Sciences, 2015, 6(8):78-93

[5] Hutchinson K, Donnell L V, Gilmore A, and Reid A. Loyalty card adoption in SME retailers: The impact upon marketing management. European Journal of Marketing, 2015, 49 (3/4):467-490.

[6]Melnyk V, BijmoltT. European Journal of Marketing, 2015, 49(3/4), 398-419, doi: http://dx.doi.org/10.1108/EJM-12-2012-0694

[7] Uncles M M D, Dowling G R, Hammond K. Journal of Consumer Marketing, 2003, 20(4), 294-316, doi:10.1108/07363760310483676

[8] Chun-Mei C, Hsian-Ming L. Total Quality Management \& Business Excellence, 2017, 12(5), 36-50, doi: 10.1080/14783363.2017.1333413

[9]Noordhoff C, Pauwels P, and Odekerken-Schroder G. International Journal of Service Industry Management, 2004, 15 (4), 351-364, doi: http://dx.doi.org/10.1108/09564230410 552040

[10] Gomez B G, Arranz A M G, Cillan J G. Journal of Retailing and Customer Services, 2012, 19(5), 492-500, doi:http://dx.doi.org/10.1016/j.jretconser.2012.06.004

[11] Liu Y. The long-term impact of loyalty programmes on consumer purchase behavior and loyalty. Journal of Marketing, 2007, 71, 19-35

[12] Lewis M. The influence of loyalty programmes and short-term promotion on customer retention. Journal of Marketing Research, 2004, XLI, 281-292

[13] Furinto A, Pawitra T, and Balqiah, T E. Designing competitive loyalty programmes: How types of programme effect customer equity. Journal of Targeting, Measurement, and Analysis for Marketing, 2009, 17(4):307-319

[14] Singh R, Khan I A. An approach to increasing customer retention and loyalty in B2C world.International. Journal of Scientific Research Publications, 2012, 2(6):1-5 
[15] Dorotic M, Bijmolt T H A, and Verhoef P C. Loyalty programmes: Current knowledge and research directions. International Journal of Management Reviews, 2102, 14 (3):217-237

[16] Turner J J, Robertson G. The boots advantage card: The advantage of customer loyalty. Journal of Marketing at Retail, 2012, 1(2):31-39

[17] Waarden L, Benavent C. Grocery retail loyalty programme effects: Self-selection or purchase behavior change? Journal of the Academy of Marketing Science, 2009, $37(3): 345-358$

[18] Jeevananda S. Influence of customer loyalty programmes on buying decision. Research Journal of Economics and Business Studies, 2011, 1(1):50-59.

[19] Acatrinei C, Puiu T V. The loyalty card: Issues in evaluating loyalty programme effectiveness. International Journal of Economic Practices and Theories, 2012, 2(3):153-164

[20] Dominici G, Guzzo R. Customer satisfaction in the hotel industry: A case study from sicily. International Journal of Marketing Studies, 2010, 2(2):3-12

[21] Jin L, Huang Y. When giving money does not work: The differential effects of monetary versus in-kind rewards in referral reward programmes. International Research in Marketing, 2013, 3(1):107-116

[22] Boonlertvanich K. Relationship between sale promotions, duration of receiving reward and customer preference: A case study on financial products. Journal of Academy of Business and Economics,2010, 10(1):53-64

[23] Pieris D, Udunuwara M. Effectiveness of loyalty cards to build the store loyalty. Journal Department of Marketing, 2012, 385-394

[24]WaardenL M. The influence of loyalty programmemembership on customer purchase behaviour. European Journal ofMarketing, 2008, 42(1/2):87-114

[25] van Osselaer S M J, Alba J W, and Manchanda P. Irrelevant information and mediatedintertemporal choice. Journal of Consumer Psychology, 2004, 42(2):443-457

[26]Coviello N E, Brodie R J, Danaher P J, and Johnston W J. How firms relate to their markets: An empirical examination of contemporary marketing practices. Journal of Marketing, 2002, 37(3):281-291

[27] Ganesan V. Rich picking with the loyalty card. Business Times, May, 2016, p. 40.

[28] Sällberg H. Customer rewards programmes: Designing incentives for repeated purchase. 
Doctoral Dissertation, Blekinge Institute of Technology, 2010

[29] Vyas P H, Sinha P K. Loyalty programmes: Practices, avenue and challenges. Working Paper, Indian Institute of Management, 2008:1-24

[30] Kongarchapatara B, Shannon R. The mediating effect of chronic stress on timepressured consumers and their shopping behaviors, The CLSG International Conference Series, 2015

[31] Van HeerdeH J, Bijmolt T H A. Decomposing the promotional revenue bump forloyalty program members versus non-members, 2005, 42(4):443-457

\section{How to cite this article:}

Mohd Abd Majid H A, Ahmad Sharif S N F, Sulong S N. Omar M, Syed Yassin S N, Raju R, Zakaria Z, and Mahamed AliF.Small and medium enterprises (SMEs) future development: A comprehensive review on customer retention programme in retaining customer loyalty. J. Fundam. Appl. Sci., 2017, 9(5S), 1006-1029. 